\title{
Texts rendering into a foreign language. Distant learning experience.
}

\author{
Margarita Kaskova, and Olga Demina* \\ Peoples' Friendship University of Russia (RUDN University), 117198 Moscow, Russian Federation
}

\begin{abstract}
This article examines the effectiveness of pedagogical techniques and means of stimulating educational motivation during the classes "Rendering and annotating text in a foreign language" in distant learning in higher education. Experimental training was conducted to test the effectiveness of the authors' electronic text rendering tutorial for students learning Italian as a second language. The experiment was carried out among the 2-nd and 3-rd year students of the Linguistics department in the Institute of Foreign Languages of the RUDN University in the 20192020 and 2020-2021 academic years. Currently e-learning has successfully integrated into the system of traditional education and is no longer seen as an alternative. The authors of this article focused on a combination of resources and tools from the Microsoft Teams platform and elaborated tutorial on rendering to motivate learners with distant learning. The article describes pedagogical practices for enhancing the motivation of students. We are talking about texts for rendering all major genres, functional styles, various topics, taking into account the level of students' preparedness. With the aim of involving students in rendering activities and active expression of their own opinion, the researchers used an " interpretive abstract "and included the paragraph "OPPINIONE " as its component. Experimental verification, its results and conclusions showed that combined rendering training based on e- tutorial developed by the authors and Microsoft Teams platform activates students' motivation and contributes to their involvement in the process. The experiment showed another strong point of distant learning: it made a great contribution to the development of students' independence, self- discipline and responsibility. 220.
\end{abstract}

\section{Introduction}

After nearly two years of distant learning, it is clear that it should remain even if the coronavirus crisis is overcome. The authors do not try to describe the advantages and possibilities of this form of education, since it has already become commonplace. According to B.E. Starichenko, today it is imposible to achieve learning goals without IT [1]. Proponents of online learning, such as S. Choi [2], D. Mathews [3], K. Leon [4], to name just a few, have recognized that e-learning has several advatages over traditional learning. " The online environment promotes student- centered learning, encourages wider students' participation and provides deep and more reasoned discussion than the traditional classical attitude " [5].

\footnotetext{
* Corresponding author: deptphilology@gmail.com
} 
Other advantages noted by various scholars include flexibility, students' autonomy, the ability to create specialized e- courses ; in addition, working on-line is less stressful for students. Meanwhile, the others who acknowledge the effectiveness of e- learning point to the fact that some students feel isolated, frustrated and lack of social interaction and communication. Many educators and teachers also note a decrease in motivation and involvement in learning activities. Without exaggeration, the formation of educational motivation of students can be called one of the central problems of distant learning in higher education. Its relevance is determined by the learning activity itself at a distance, by updating the content of education, by developing students' techniques for the independent acquisition of knowledge, and the development of activity. Today, the most acute problems in the field of on-line education are associated with the demotivation of the bulk of students, which leads to a decrease in basic indicators of their education. The authors of this article focused on using the potential of combined rendering learning based on the author's e-learning tutorial and the Microsoft Teams platform to motivate learners in distant learning.

\section{Research methodology}

The question of optimizing educational motivation in the classroom while learning the subject "Rendering and annotating texts in a foreign language" is considered by the authors in a practical direction. The subject of this article is a set of pedagogical methods techniques and means of stimulating learning motivation in the classroom on the Microsoft Teams platform based on e-tutorial developed by the authors. The experiment is carried out among 2-nd and 3-rd year students in the Institute of Foreign Languages of the RUDN University in the 2019- 2020 and 2020-2021 academic years. In accordance with the curriculum, 72 academic hours are allocated for the subject "Rendering and annotating texts in a foreign language", 32 hours - for classroom studies and 40 hours - for students' independent work. The total number of students taking part in the experimental study was 23 .

The purpose of the experimental training was to test the feasibility and effectiveness of the proposed measures to enhance the motivation of the studies in distant learning in higher education.

- The complex of pedagogical conditions is understood, firstly, the content of education. Experimental training was based on e- tutorial for rendering texts in Italian developed by the authors.

The theoretical basis of the textbook was the research of the scientific school of A.I. Novikov and the results of the experiments made by his disciples - followers N.M. Nesterova, N.P. Peshkova and others. In the works of scientists, the following issues were deeply elucidated : the problem of ontology of meaning, patterns and mechanisms of meaning formation, understanding the text when summarizing, interpreting information, and the process of folding and compressing information was investigated. .[6,7,8,]

The tutorial contains authentic texts representing all major genres, functional styles and varioius topics b taking into account the level of students' preparedness, which makes the study of the Italian language interesting and informative. We should mention contemporary Italian writers, whiose works are also presented in the tutorial : G. Rodari, S. Agnelli, N. Ammaniti, A. Campanile, S. Benni, G. Ducci.

Each text is accompanied by tasks and exercises that help the teacher in mastering the techniques of rendering. Special attention should be paid to the tasks for the develooment of memory, thinking, the logic of presentation and as well as teaching of analysis and synthesis the formation of a linguistic guess.

- Secondly, specific firms of organizing educational activities, many tools and resources are provided by the Microsoft Teams platform. For example, the lesson module was actively 
used to implement and consolidate new material. The file- resource provides an opportunity to download educational materials in various formats - a slide-show and a presentation, URL references, multimedia is thus one of the most flexible resource. Activity quiz is a powerful tool that students used for self-assessment . which led to an increase in their activity in the classroom and interest in the learning process of rendering.

- Third, innovative methods and innovative teaching methods. The researchers note that to be able to render $t$ means to be able to summarize the main content of what has been read , the essence of a work in a foreign language. The rendering process ends with the writing of an abstract that meets the basic requirements: objectivity, completeness of presentation , unity of form, structure and does not imply the expression of the personal view of the referent. Reducing the volume of the text is provided up to $30 \%$ of the original. However, the tasks of educational rendering in the Linguistics department are much broader than just drawing up an abstract.

B.A. Cheremisov, back in the 70-s of the last century, proposed the term "educational rendering". Educational rendering is one of the ways of teaching a foreign language, allowing to consolidate and enrich knowledge of the studied language, to expand the general educational level of students, and its characteristic method of receiving and processing information, develops the students' creative abilities, promotes the activation of the entire motivational sphere, improves the skills of independent work with literature, so necessary for a modern person for self - education. Drawing up an annotation is considered as a necessary part of the process of teaching rendering activity. Such an approach to educational rendering is fundamentally new and is determined by the goals of studying a foreign language in a linguistic university.

As the main type of abstract, we propose to use an " interpretive abstract ", which , along with the presentation of bibliographic data, content, problems of the text, should have a paragraph " OPPINIONE “, in which students give their assessment of the issue raised , present arguments in favor of their point of view, oppose. Thus the following scheme is obtained the author. At the same time, students can use all available resources and tools of the Microsoft Teams platform for argumentation of any kind like a quiz, slide-show, presentation, etc. It should be noted that the requirement for the ratio of the volume of the abstract to the original text $-30 \%$ is obvious for students - linguists, whose first foreign language is English. However, to involve students in rendering activities and actively express their own opinion we added another $10 \%$. Thus the following scheme is obtained: abstract $(30 \%)+$ paragraph «OPPINIONE» $(10 \%)=40 \%$

The above formula naturally refers to a written statement.

- Fourthly, the initiative and activity of students has a positive reinforcement in the form of scores awarded. Table 1 illustrates the ratio of scores and components of the abstract in percentage terms.

Table 1. Scoring table

\begin{tabular}{|l|l|c|c|}
\hline & \multicolumn{1}{|c|}{ Abstract components } & Scores example & Percentage \\
\hline 1. & ANNOTAZIONE I & 1 & $10 \%$ \\
\hline 2. & ANNOTAZIONE II & 1 & $10 \%$ \\
\hline 3. & SOMMARIO & 2 & $20 \%$ \\
\hline 4. & PROBLEMA & 1 & $10 \%$ \\
\hline 5. & OPPINIONE & 4 & $40 \%$ \\
\hline 6. & $\begin{array}{l}\text { LOGGICA, COERENZA DEL } \\
\text { TESTO }\end{array}$ & 1 & $10 \%$ \\
\hline & totale & 10 & $100 \%$ \\
\hline
\end{tabular}




\section{Research results}

The purpose of the experimental training was to test the feasibility and effectiveness of the proposed measures to enhance the motivation of students in distant learning in higher education. In the course of training particular tasks were also solved:

- To check the availability and feasibility of selected authentic texts for junior students;

- To check the effectiveness of using individual tasks in order to improve them in the course of training.

Two groups of students, one group of third - year students and one group of second- year students of the department of linguistics, profile translation and translation studies, learning Italian as a second foreign language, took part in the experimental teaching. Group 1 included 11 participant: 8 girls and 3 boys, group $2-12$ students. The total number of participants is 23.

The training began with an introductory lessons, the purpose of which was to inform students about the upcoming work with an e-tutorial on the Microsoft Teams platform about pedagogical techniques of rendering; about the scoring system. The diagnostic cut was carried out in February 2019 among second-year students, which corresponds to the second semester of the first year of learning the second foreign at the Linguistics department. The purpose of diagnostic cut № 1 was to establish the initial level of knowledge and students’ skills in the field of rendering according to the selected criteria. The results are presented in Table 2.

Table 2. Diagnostic section results table№1

\begin{tabular}{|c|c|c|c|c|c|c|c|}
\hline \multirow{2}{*}{$\begin{array}{c}\text { Participa } \\
\text { nt }\end{array}$} & \multirow{2}{*}{$\begin{array}{l}\text { Complianc } \\
\text { e with } \\
\text { abstract } \\
\text { structure }\end{array}$} & \multirow{2}{*}{$\begin{array}{c}\text { Abstrac } \\
\mathbf{t} \\
\text { volume } \\
\text { ( least } \\
\text { words ) }\end{array}$} & \multirow{2}{*}{$\begin{array}{c}\text { Abstrac } \\
\text { t } \\
\text { volume } \\
(\%)\end{array}$} & \multirow{2}{*}{$\begin{array}{c}\text { OPPINION } \\
\text { E }\end{array}$} & \multicolumn{3}{|c|}{$\begin{array}{l}\text { Resource usage of } \\
\text { Maicrosoftteams }\end{array}$} \\
\hline & & & & & $\begin{array}{c}\text { Audi } \\
\text { o }\end{array}$ & $\begin{array}{c}\text { Vide } \\
\text { o }\end{array}$ & $\begin{array}{c}\text { Presentatio } \\
\text { n }\end{array}$ \\
\hline I group & $34,42 \%$ & 137 & $55,2 \%$ & $3,0 \%$ & $0 \%$ & $0 \%$ & $0 \%$ \\
\hline II group & $24,6 \%$ & 159 & $64,1 \%$ & $2,2 \%$ & $0 \%$ & $0 \%$ & $0 \%$ \\
\hline $\begin{array}{l}\text { Total } \\
\text { average }\end{array}$ & $33,5 \%$ & 148 & $\begin{array}{l}59,65 \\
\%\end{array}$ & $2,6 \%$ & $0 \%$ & $0 \%$ & $0 \%$ \\
\hline
\end{tabular}

As can be seen from Table 2 , the cut results for the parameters selected for analysis in both groups are approximately the same. The data on compliance with the structure of the abstract indicate the lack of a clear understanding of the models for its construction. Also, the correspondence of the volume of the abstract of $30 \%$ was not maintained due to unnecessary detailing, copying the sentences of the original text, repetitions. From the data in the table, it is obvious that the resources and tools of the Microsoft Teams platform were not used by the students. There is an explanation for this fact. Unfortunately, the expression of one's own attitude to the problem raised in the text was limited to the words " interesting / not interesting".

Experimental teaching continued in accordance with the curriculum of the subject "Rendering and annotating texts in a foreign language", which amounted to 72 academic hours , 32 hours for classroom studies and 40 hours for students' independent work. In may, at the end of the semester < a snapshot was taken to record changes in the quality of the abstract over the four months of study. Its results illustrate the improvement in the quality of rendering activity in terms of compliance with the structure of the abstract . However, its volume has decreased insignificantly, which indicates certain difficulties in analytical and synthetic activity - the extraction of essential elements of the text and their transfer in generalized form. Students of the 1-st group used the sound track from the movie they liked, 
and two students illustrated their answer with photographs. The results are illustrated in Table № 3 .

Table 3. Control cut results №2

\begin{tabular}{|c|c|c|c|c|c|c|c|}
\hline \multirow{2}{*}{$\underset{\text { nt }}{\text { Participa }}$} & \multirow{2}{*}{$\begin{array}{l}\text { Complianc } \\
\text { e with } \\
\text { abstract } \\
\text { structure }\end{array}$} & \multirow{2}{*}{$\begin{array}{c}\text { Abstrac } \\
\quad t \\
\text { volume } \\
\text { ( least } \\
\text { words) }\end{array}$} & \multirow{2}{*}{$\begin{array}{c}\text { Abstrac } \\
\text { t } \\
\text { volume } \\
(\%)\end{array}$} & \multirow{2}{*}{$\begin{array}{l}\text { OPPINION } \\
\text { E }\end{array}$} & \multicolumn{3}{|c|}{$\begin{array}{c}\text { Resource usage of Microsoft } \\
\text { Teams }\end{array}$} \\
\hline & & & & & $\begin{array}{c}\text { Audi } \\
\text { o }\end{array}$ & Video & $\begin{array}{c}\text { Presentatio } \\
n\end{array}$ \\
\hline I group & $50,70 \%$ & 127 & $50,2 \%$ & $4,7 \%$ & $1,1 \%$ & $2,2 \%$ & $0 \%$ \\
\hline II group & $47 \%$ & 140 & $59,1 \%$ & $5,9 \%$ & $0 \%$ & $0 \%$ & $0 \%$ \\
\hline $\begin{array}{l}\text { Total } \\
\text { average }\end{array}$ & $48,85 \%$ & 133,5 & $\begin{array}{l}54,65 \\
\%\end{array}$ & $5,3 \%$ & $\begin{array}{l}0,55 \\
\%\end{array}$ & $1,1 \%$ & $0 \%$ \\
\hline
\end{tabular}

The second stage of experiential learning $(32+40$ hours, September-December 20202021 academic year) was carried out in the same groups in the third year. In September, at the second lesson, a check-up test was given to the students in order to assess their knowledge after a three-month summer break. However the test results showed stable good performance: there is no significant difference between the indicators of the control and test.

The changes are recorded in the use of resources and tools of the Microsoft teams platform. Students were happy to present photos and videos of their travels. Unfortunately, only one student of group I used the resource presentation. Table 4 illustrates the comparison of the average data of the control (slice \# 2) and intermediate slices (slice \# 3) by groups

Table № 4. Comparison Chart of cut results ( № 2 № 3 )

\begin{tabular}{|l|c|c|c|c|c|c|c|}
\hline \multirow{2}{*}{$\begin{array}{c}\text { № } \\
\text { group }\end{array}$} & $\begin{array}{c}\text { Compliance } \\
\text { with } \\
\text { abstract } \\
\text { structure }\end{array}$ & $\begin{array}{c}\text { Abstract } \\
\text { volume } \\
\text { (least } \\
\text { words ) }\end{array}$ & $\begin{array}{c}\text { Abstract } \\
\text { volume } \\
(\%)\end{array}$ & OPPINIONE & \multicolumn{3}{|c|}{$\begin{array}{c}\text { Resources usage of } \\
\text { Maicrosoftteams }\end{array}$} \\
\cline { 3 - 8 } & & & & & Audio & Video & Presentation \\
\hline I & $50,70 \%$ & 127 & $50,2 \%$ & $4,7 \%$ & $1,1 \%$ & $2,2 \%$ & $0 \%$ \\
\hline group & $53 \%$ & 129 & $53,40 \%$ & $8,18 \%$ & $0 \%$ & $4,4 \%$ & $1,1 \%$ \\
\hline $\begin{array}{l}\text { II } \\
\text { group }\end{array}$ & $47 \%$ & 140 & $59,1 \%$ & $5,9 \%$ & $0 \%$ & $0 \%$ & $0 \%$ \\
\cline { 2 - 8 } & $49,2 \%$ & 141 & $61,80 \%$ & $7 \%$ & $0 \%$ & $2,4 \%$ & $0 \%$ \\
\hline
\end{tabular}

The experience training ended with a final cut in December 2020. An analysis of the abstracts showed that the quality of student work has improved significantly. It should be noted that the time for writing an abstract was reduced from 45 minutes of the diagnostic cut to 15 (on average) of the final cut. There is an increase in student initiative in using the resources and tools of the Maicrosoftteams platform when creating OPPINIONE on the problem of text.

The results of the final section indicate that students began to better orient themselves in the compositional structure of the text, more quickly identify essential information and convey it in a concise form. The decrease in the volume of the abstract is indicated by the data in Table 5, despite the fact that the volume of texts for abstract activity has steadily increased throughout the entire period of experimental training. The structure of the abstract became clear $(86.35 \%$ on average). The results are presented in the form of table 5 . 
Table 5. Comparison Chart of the cut results №4

\begin{tabular}{|c|c|c|c|c|c|c|c|}
\hline \multirow{2}{*}{$\begin{array}{c}\text { Participa } \\
\mathbf{n}\end{array}$} & $\begin{array}{c}\text { Complianc } \\
\mathbf{e} \text { with } \\
\text { abstract } \\
\text { structure }\end{array}$ & $\begin{array}{c}\text { Abstrac } \\
\mathbf{t} \\
\text { volume } \\
\text { (least } \\
\text { words) }\end{array}$ & $\begin{array}{c}\text { Abstrac } \\
\mathbf{t} \\
\text { volume } \\
\mathbf{( \% )}\end{array}$ & $\begin{array}{c}\text { OPPINION } \\
\mathbf{E}\end{array}$ & & \multicolumn{3}{|c|}{$\begin{array}{c}\text { Resouce usage of } \\
\text { Maicrosoftteams }\end{array}$} \\
\cline { 6 - 8 } & & $\begin{array}{c}\text { Audi } \\
\mathbf{0}\end{array}$ & $\begin{array}{c}\text { Vide } \\
\mathbf{0}\end{array}$ & $\begin{array}{c}\text { Presentatio } \\
\mathbf{n}\end{array}$ \\
\hline I group & $87,7 \%$ & 119 & $40,2 \%$ & $8,7 \%$ & $3,3 \%$ & $2,2 \%$ & $1,1 \%$ \\
\hline II group & $85 \%$ & 120 & $44,1 \%$ & $8,9 \%$ & $1,1 \%$ & $1,2 \%$ & $0 \%$ \\
\hline $\begin{array}{c}\text { Total } \\
\text { average }\end{array}$ & $86,35 \%$ & 119,5 & $\begin{array}{c}42,15 \\
\%\end{array}$ & $5,3 \%$ & $2,2 \%$ & $1,7 \%$ & $0,55 \%$ \\
\hline
\end{tabular}

\section{Results and discussion.}

In order to get a feedback while graduating there was organized a conference focused on discussing the final received results. It was noted that the platform of Microsoft teams is a crucially important constitutional component of the modern education system due to the factor that a great amount of students who had regularly used the platform Microsoft teams have significantly improved their academic performance. The participants of the experience have highly valued the list of lesson topics in a student e-book elaborated by the group of authors providing tutorial rendering texts from a source language into a target one. It was recorded that the online tutorial course corresponds to the reality of the state-of-the-art education system, meets students' wishes who are going through a complicated making-up of personality stage: at the age of 18-20 years old - a phase of self-determination, selfidentification, search for answers to the long-standing questions of existence.

The students evaluated the potential benefits of the platform Microsoft teams for both targets: advancing a foreign language and further self-education stage. However the role of a tutor should not be underestimated especially in such functions as guidance, monitoring and control of the students' academic performance, as a fruitful cooperation between a student and a professor is a cornerstone of the teaching and learning process. But it should be expressed great regret that the students with lower second-class and third-class honours were dissatisfied with their academic performance results on the course in question and finally they expressed their disillusionment of lost opportunities.

Approximately $78,2 \%$ that amounts to 18 students who delivered their satisfaction with the academic syllabus, teaching and learning process, as well as with their academic progress and performance results in mastering a foreign language. The experiment proved that the key strength of distant learning: it has appreciably contributed to independence of learning process, boosted their discipline and responsibility.

\section{Conclusions}

Experimental learning, test results, analysis of research papers, personal observations and final discussions helped to draw the following conclusions:

- On-line tutorial course on rendering texts from a source language into a target one based on a digital textbook elaborated by the authors of this article along with the Microsoft teams tools proved its efficacy and relevance given the empirical data.

- The recommended section «OPPINIONE» plays a role of utmost importance in boosting students' motivational activity, offers sharing of personal experience, impressions, thoughts and feelings. Expression of personal points of view, desire for being heard and understood contribute greatly to students' involvement into educational process in the long-run of learning and teaching course. 
- The authors regret to inform that not all the students have demonstrated a high motivation level. Those students who refused to resort to the benefits of the Microsoft teams features failed in achieving great success.

- The final discussion along with the received feedback reflected a high level of satisfaction by online learning on the Microsoft teams platform. The students highly rated the potential of the resource thanks to which they mastered, reinforced their skills, brushed up knowledge of a foreign language. The students with lower academic performance were discontented with the final results because of lost opportunities.

- In general, the students of the Institute of Foreign Languages find Microsoft teams platform useful and productive as it helps to be motivated, hone skills, broaden one's outlook. They stressed the special features of the Microsoft teams platform which aims at deepening one's knowledge and encourages independence of learning process.

- The Microsoft teams platform is multifunctional and flexible both for students and professors, as it reflects up-to-date tendency in educational system due to its dynamic and student-oriented nature.

\section{References}

1. B.E.Starichenko, Pedagogical Education in Russia, 3, 23 (2013)

2. Findings from the condition of education 2002: Nontraditional undergraduates (Report No. NCES 2002-012). Washington, DC: U.S. Department of Education, National Center for Education Statistics, (2002)

3. D.Matthews, , The Journal, 27(2), 54 (1999)

4. K. Swan, P. Shea, E. Frederickson, A. Pickett, W. Pelz, G. Maher, Journal of Educational Computing Research, 23(4), 389 (2000)

5. Ya Ni, Journal of Public Affairs Education, 19(2), 199 (2013)

6. N. M. Nesterova, Vestnik CHelGU, 25(240), 58, 112 (2011)

7. A.I. Novikov, YAzykovoe soznanie, Soderzhanie i funkcionirovanie: Mezhdunarodnyj simpozium po psiholingvistike i teorii kommunikacii, 170 (2000)

8. A.I. Novikov, Tekst i ego smyslovye dominanty (Azbukovnik, 2007)

9. M. Kaskova, T. Dugina, A. Zabolotskikh, 10th International Conference on Education and New Learning Technologies, 2556 (2018)

10. M.E. Kaskova, Praktikum po referirovaniyu i annotirovaniyu tekstov na ital'yanskom yazyke (RUDN, 2020) 